\title{
JUURNAL.RU
}

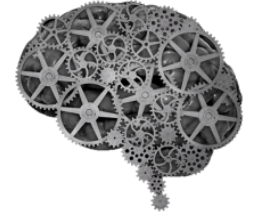

COMPANY GROUP

"INTELLEKT"

\author{
Артемкин А.О., Костин К.Б., Пичхидзе С.Я. \\ СГТУ им. Ю.А. Гагарина \\ Саратов, Россия
}

doi: 10.18411/1j2016-5-3-01

\section{Гидроксиапатит-покрытие в электролите-суспензии}

$\mathrm{B}$ продолжение работ [1,2] при получении покрытий порошка $\mathrm{ZrO} 2$ методом микродугового оксидирования (МДО) вносили гидроксиапатит (ГА).

Цель настоящего исследования заключалась в получении прочного биоактивного покрытия на основе $\mathrm{ZrO} 2$ и гидроксиапатита.

Методика эксперимента. Формирование МДО-покрытия проводили на образцах из титанового сплава ВТ1-0 размерами $15 \times 15 \times 1,5$ мм в анодном режиме при плотности тока $\mathrm{j}=110 \mathrm{~A} /$ дм2 в течение 15 мин в растворе, содержащем 3 г/л NaOH, 4 г/л ZrO2 и 4 г/л порошка ГА дисперсностью 40 мкм. Исследование морфологии поверхности и состава образцов проводилось методом РЭМ/ЭДРА. Для снятия статического заряда на поверхности образцов наносилась тонкая пленка Аu методом магнетронного напыления.

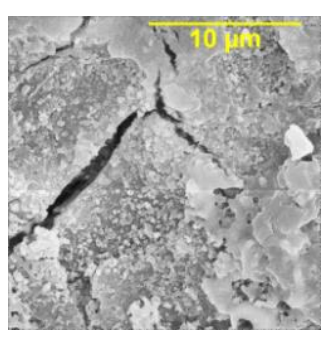

a

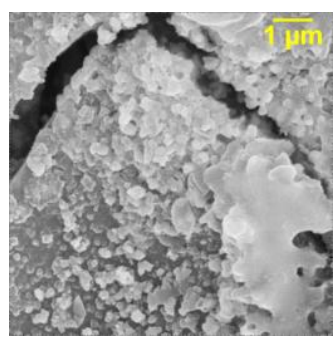

б

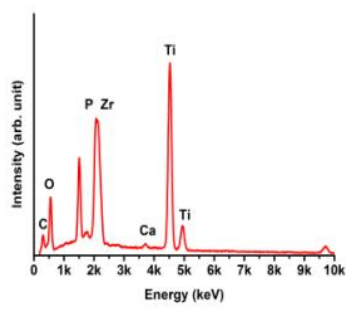

B

Рис. 1. Данные РЭМ поверхности при увеличении: a) $2500 x, \sigma-10000 x$

Рис.2. ЭДРА-спектр поверхности

Отмечено, что при добавлении в раствор щелочи порошков $\mathrm{ZrO} 2$ и ГА выход в режим появления микроразрядов происходил быстрее, чем в растворе щелочи. Покрытие содержит трещины, неоплавленные и оплавленные частицы 
порошков $\mathrm{ZrO} 2$ и ГА, кратеры микроразрядов. Линии циркония накладываются на линии фосфора.

\section{Литература:}

1. Василенко А.А., Герасимов С.В., Денисов Д.С., Кривенцов Н.М., Поршнев А.В., Пичхидзе С.Я., Нечаев Г.Г. Характеристики покрытий, полученных методом МДО в электролите-суспензии. Саратов: СГТУ. 2015.-4c.

2. Василенко А.А., Денисов Д.С., Герасимов С.В., Кривенцов Н.М., Поршнев А.В., Пичхидзе С.Я. МДО-покрытия в электролите-суспензии. Самара: ЛЖурнал, 2016. - 1c. 